\title{
Career Maturity of Female College Students, A Case Study of University of South China
}

\author{
Lishan Rong ${ }^{1}$, Lv Yijin ${ }^{1}$, Jiaquan Zhou ${ }^{1}$, Baoping Liu ${ }^{2,}$ * \\ ${ }^{1}$ Hunan Provincial Key Laboratory of Pollution Control and Resources Technology, University of \\ South China, Hengyang, China \\ ${ }^{2}$ School of Management, University of South China, Hengyang City, Hunan Province, China
}

Keywords: Career maturity, Female college students, Application analysis

Abstract: Career is very important to women and scholars usually use "career maturity" to measure personal career development. The individual strengths and weaknesses can be found through measuring the career maturity and we could improve our professional capacity in carrying out more effective self-career planning and management in this way. Through the establishment and apply of female career maturity model, we give a empirical analysis on the career maturity of female college students.

The individual strengths and weaknesses of professional attitude and professional capacity can be found through measuring career maturity(Ma Yuan, 2003).it is popularly applied by the scholars now and could improve our professional capacity in carrying out more effective self-career planning and management(Kikawa S,2016).Here we mainly review the theories of career maturity and establish female career maturity model and adding group variables based on previous study(Westbrook BW,1983) We measure and analyze female college students career maturity through questionnaires and point out its development characteristics(Betz NE,1988).It can provide realistic basis for the career development of female college students.

\section{Establishment of Career Maturity Model}

Crites established youth career maturity model through summarizing its predecessors' study (Crites, 1996). This model study on the career option attitude and professional competence of young students in the process of career option attitude and professional competence in young students' career transition period. This model has great theoretical and practical significance for the people to study the career maturity (Zhou Wenxia, 2006).

Combined with changes in career development, we divide gender career maturity in four dimensions based on the youth career maturity model: career selection content, career selection process, career gender, career development process.

Career selection content includes two specific maturity factors, namely the consistency of career selection and the reality of career selection. Career selection process includes the ability of career selection and the attitude of career selection (Talley K G, 2017). Career gender consists of the awareness of career gender and the role of career gender. Career development process includes the change of career development and the obstacle of career development (Mckillop E, 2017). 


\section{The Application Analysis of Career Maturity of Female College Students}

We conducted a formal investigation on the career maturity of female college students, using undergraduates of University of South China as the samples. We sent a total of 430 questionnaires, 392 back, and we got 348 valid questionnaires, to meet the requirement that the number of people tested is more than five times the scale items. SPSS software is used for data processing and analysis(XIE Ya-ping, 2011).

\subsection{Reliability and validity analysis}

\subsubsection{Reliability analysis}

According psychometric, it can be accepted if reliability coefficient were 0.70(Yang Xuhua, 2011). or more. As shown in Table 1, the reliability of the questionnaire can be accepted in general.

Table 1 Career Maturity reliability index $(\mathrm{N}=348)$

\begin{tabular}{cccccc}
\hline $\begin{array}{c}\text { Reliability } \\
\text { index }\end{array}$ & $\begin{array}{c}\text { Career } \\
\text { attitudes }\end{array}$ & $\begin{array}{c}\text { Career } \\
\text { competence }\end{array}$ & $\begin{array}{c}\text { Career } \\
\text { gender }\end{array}$ & $\begin{array}{c}\text { Career } \\
\text { progress }\end{array}$ & $\begin{array}{c}\text { Career } \\
\text { maturity }\end{array}$ \\
\hline $\begin{array}{c}\text { Split-half } \\
\text { reliability }\end{array}$ & 0.7356 & 0.7105 & 0.7038 & 0.7043 & 0.8046 \\
$\begin{array}{c}\text { Cronbach } \alpha \\
\text { coefficient }\end{array}$ & 0.7193 & 0.7010 & 0.7126 & 0.7158 & 0.8400 \\
\hline
\end{tabular}

\subsubsection{Validity analysis}

The construct validity of questionnaires is tested by principal component analysis method. Accessing the data by average orthogonal rotation, we extract factors as the ceigenvalues of factors is greater than 1 . The results showed that the load values of all 55 items are above 0.4, the KMO of four questionnaire are all higher than 0.80 , the total amount of variance explained is greater than $55 \%$. Therefore, the questionnaires have good construct validity.

Formal questionnaires include four grade-level students, the statistical results showed that: student groups of different grade levels have significant differences in the scores. Group characteristics can be distinguished through questionnaires, the questionnaires has good discriminant validity (Table 2).

Table 2 Single factor analysis of variance of different grade level students' scores

\begin{tabular}{lllllc}
\hline & Career attitudes & Career competence & Career gender & Career progress Career maturity \\
\hline $\mathrm{F}$ & 3.268 & 2.945 & 3.196 & 2.602 & 2.715 \\
$\mathrm{P}$ & $0.35^{*}$ & $0.42^{*}$ & $0.38^{*}$ & $0.47^{*}$ & $0.45^{*}$ \\
\hline
\end{tabular}

Notes: ${ }^{*} \mathrm{P}<0.05$

We conducted reliability and validity analysis on career maturity questionnaire in this way. The results show that the indicators of the questionnaire are acceptable. There are four factors that constitute the career attitudes questionnaire: career choices and independence, career choice orientation, career choice certainty, career choices compromise. There are three factors that constitute the career competence questionnaire: occupational rules and problem solving skills, the ability to obtain career information, the ability to self-assessment. There are two factors that constitute the career gender questionnaire: gender awareness, gender roles. There are two factors that constitute the career progress questionnaire: the cognitive of career difficult, the attitude for career transition. This result is the same with the pre-test result and it indicates that these factors are 
relatively stable and the analysis based on the statistical analysis of these factors is credible.

\subsection{The analysis of the results}

We get the questionnaire's score by adding up each topic score points. Career maturity questionnaires' total score is the sum of four questionnaire's score. The higher the score, the higher level of career maturity development. Statistical results showed that:

\subsubsection{Gender differences}

The samples are tested for gender, gender scores and the independence test results are shown in Table 3

Table 3 The average gender score of each questionnaire and independent sample test

\begin{tabular}{cccccc}
\hline & Career attitudes & Career competence & Career gender & Career progress Career maturity \\
\hline Male & 76 & 56.3 & 27.4 & 24.2 & 183.7 \\
Female & 75 & 57.3 & 26.8 & 26.1 & 185.2 \\
Mann & 0.27 & 0.333 & 0.206 & $0.016^{*}$ & 0.436 \\
-whitney Test & 0.251 & 0.612 & 0.661 & $0.001^{*}$ & 0.000 \\
Moses Test & 0.572 & 0.882 & 0.726 & 0.095 & 0.018 \\
$\begin{array}{c}\text { Two-sample } \\
\text { Kolmogorov-smirnov }\end{array}$ & 0.434 & 0.475 & 0.475 & 0.146 & 0.168 \\
$\quad$ Test & & 1.000 & 1.000 & 1.000 & 0.997 \\
\hline
\end{tabular}

As can be seen from the statistics, except there are some differences in the cognitive aspects of career transition, there were not significantly different between men and women in terms of career maturity. As can be seen from the statistics, the career maturity level of female students is slightly higher than the male, which may be related with female complex career development environment.

\subsubsection{Grade levels and career maturity}

We have conducted a survey of four grade levels with the formal questionnaire. ANOVA is applied for the test for differences in questionnaire scores. You can see the scores of categorical variables and the results of variance analysis(Table 4)

Table 4 The average score of different grades and single factor analysis of variance

\begin{tabular}{cccccc}
\hline Grades & $\begin{array}{c}\text { Career } \\
\text { attitudes }\end{array}$ & $\begin{array}{c}\text { Career } \\
\text { competence }\end{array}$ & $\begin{array}{c}\text { Career } \\
\text { gender }\end{array}$ & $\begin{array}{c}\text { Career } \\
\text { progress }\end{array}$ & Career maturity \\
\hline Grade 1 & 75.5000 & 57.6750 & 26.6750 & 26.0000 & 185.8500 \\
Grade 2 & 80.7317 & 58.2439 & 29.5610 & 27.1220 & 195.6585 \\
Grade 3 & 79.3333 & 59.1818 & 28.1212 & 25.8788 & 192.5152 \\
Grade 4 & 69.4500 & 54.3167 & 23.8000 & 24.3038 & 171.8667 \\
F & 3.268 & 2.945 & 3.196 & 2.602 & 2.715 \\
P & $0.35^{*}$ & $0.42^{*}$ & $0.38^{*}$ & $0.47^{*}$ & $0.45^{*}$ \\
\hline
\end{tabular}

Notes: ${ }^{*} \mathrm{P}<0.05$ 
As can be seen from the statistics, there are no significant differences between Grade 2 and Grade 3 in their career maturity level. However, there are significant differences in their career maturity level compared to other grades such as Grade 1 and Grade 2. The career maturity level of Grade 2 and Grade 3 is higher Grade 1 is high and Grade 4 is low. The survey results is different from previous studies. The main reason for the differences maybe that low levels is caused by the difficulties of career progress.

\subsubsection{Control point and career maturity}

Control point is the individual's power to control their own lives in interaction with the surrounding environment (Zhao Qian, 2010). It is the responsibility and cognitive of their own behavior. We use the revised Rotter Psychological Control Scale to investigate into female college students and the female college students were divided into into three categories: internal control students, mid-control students, external control students. We use the mean of control point scores $(\bar{X})$ and standard deviation(S) as the criteria for the classification:

Internal control: control point score $\leq \bar{X}-0.5 \mathrm{~S}$

Mid-control: $\bar{X}+0.5 S<$ control point score $<\bar{X}+0.5 S$

External control: control point score $\geq \bar{X}+0.5 \mathrm{~S}$

Table 5 The scores of different control points and ANOVA results

\begin{tabular}{ccccccc}
\hline $\begin{array}{c}\text { Control } \\
\text { types }\end{array}$ & $\begin{array}{c}\text { Career } \\
\text { attitudes }\end{array}$ & $\begin{array}{c}\text { Career } \\
\text { competence }\end{array}$ & $\begin{array}{c}\text { Career } \\
\text { gender }\end{array}$ & $\begin{array}{c}\text { Career } \\
\text { progress }\end{array}$ & $\begin{array}{c}\text { Career } \\
\text { maturity }\end{array}$ & $\mathrm{N}$ \\
\hline $\begin{array}{c}\text { Internal } \\
\text { control }\end{array}$ & 81.35 & 62.40 & 31.52 & 29.14 & 194.41 & 101 \\
$\begin{array}{c}\text { Mid- } \\
\text { control }\end{array}$ & 75.41 & 56.95 & 27.10 & 25.90 & 185.36 & 71 \\
$\begin{array}{c}\text { External } \\
\text { control }\end{array}$ & 66.74 & 51.17 & 20.41 & 23.72 & 162.04 & 80 \\
F & 28.513 & 21.432 & 8.591 & 10.320 & 30.252 & \\
P & $.000^{* *}$ & $.000^{* *}$ & $.000^{* *}$ & $.000^{* *}$ & $.000^{* *}$ & \\
\hline
\end{tabular}

Notes: ${ }^{* *} \mathrm{P}<0.01$

We get the average score differences of career maturity questionnaire by ANOVA analysis. The statistical results is in Table 5.

The ANOVA results shows that: on the average scores of career maturity questionnaires, internal control students $>$ mid-control students $>$ external control students. There are significant differences between internal control students, mid-control students and external control students on the scores of career maturity questionnaires.

\subsubsection{Factor analysis}

On factor statistical results, although female students have no significant difference with the male, but the female score of career investment is high than the male. The reality compromise scores of the male is higher than the female. On the other side, the female face more career adaptation problems in the future. The female's career gender score is lower than the male, indicating that the female are somewhat lacking of career consciousness and will be faced with difficulties of the choice of roles and is more confusion in career development. In terms of career transition, the female scored significantly higher than the male, indicating that the female's career development will face more uncertainty. 


\section{Conclusion}

Through investigation and analysis, we can see that are some differences in the cognitive of career transition between the female students and the male students. On the average scores of career maturity questionnaires, internal control students $>$ mid-control students $>$ external control students. However there are no significantly difference in career maturity between the female students and the male students. On grade level, grade 2 and grade 2 have no significant difference in career maturity level, but compared to other grades, there are significant differences in their career maturity level.

Female college students is an important part of college and is an important force for social development (Feng Sihai, 2012).. Currently there is some gender discrimination in education, employment and career development. Our society should provide a good social environment for the female college students’ careers.

\section{Acknowledgements}

Educational reform project of University of South China (2015JG010).

\section{References}

[1] Ma Yuan. Questionnaire Construct and Influencing Factors of Career Maturity of Youth Before Entering the Workforce. Guangzhou: Jinan University, 2003,5.

[2] Kikawa S. Attachment to Parents in Female University Students and Its Effect on Career Development[J]. Japanese Journal of Personality, 2016, 25(1):89-92.

[3] Super, D.E. The psychology of careers. N.Y: Harper, ROW, 1957,12-35

[4] Westbrook BW. Career maturity: The concept, the instrument, and the research.In WB Walsh \& SH Osipow, Handbook of vocational psychology : foundations. 1983,263-304.

[5] Betz NE. The assessment of career development and maturity. In: WB Walsh \& SH Osipow, Career decision making. 1988,81-99.

[6] Crites, John O. Savickas, Mark L. Revision of the Career Maturity Inventory. Journal of career Assessment, 1996 (4): 131-138.

[7] Zhou Wenxia. Career Success: From Concept to Practice. Shanghai: Fudan University Press, 2006: 76-77 Talley K G, Ortiz A M. Women's interest development and motivations to persist as college students in STEM: a mixed methods analysis of views and voices from a Hispanic-Serving Institution[J]. International Journal of Stem Education, 2017, 4(1):5.

[8] Mckillop E, Moorosi P. Career development of English female head-teachers: influences, decisions and perceptions[J]. School Leadership \& Management, 2017(1):1-20.

[9] XIE Ya-ping, ZHOU Fang. Study on College Students' Career Maturity and Its Impact factors. Journal of Taiyuan University of Technology, 2011.02

[10] Yang Xuhua. Exploration and verification for college studengts' Career Maturity Structure. China Human Resources Development, 2011.08

[11] Zhao Qian. Effect of Locus of Control on Junior College Students' Career Maturity. Chinese Journal of Health Psychology, 2010.08

[12] Feng Sihai, Social Support, Career Maturity and Subjective Well-being of College Students. Psychological research, 2012.04 